\title{
Forest modelling and visualisation - state of the art and perspectives
}

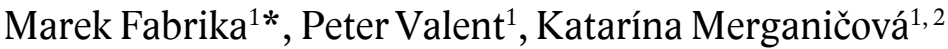 \\ ${ }^{1}$ Technical University in Zvolen, Faculty of Forestry, T. G. Masaryka 24, SK-960 01 Zvolen, Slovak Republic \\ ${ }^{2}$ Czech University of Life Sciences Prague, Faculty of Forestry and Wood Sciences, Kamýcká 129, CZ - 16500 Praha 6 -Suchdol, \\ Czech Republic
}

\begin{abstract}
The paper provides a detailed overview on forest models from various perspectives. The presented classification scheme of forest models uses concept, object, space and time as variables to place models in specific categories and thus provides an integrated approach for model categorisation. A short description of individual categories with the examples of models helps to understand their nature. In total 34 forest models were classified according to the created scheme. Forest visualisation has also an important place in forest modelling. Here it is described from the point of different visualisations methods and used technologies. Inputs that are necessary for the models but are often not available and need to be derived using specialised tools - various forms of data generators are presented too. Important perspectives and challenges of further development of forest models and visualisation technologies were specified as well.
\end{abstract}

Key words: simulations; prognostic tools; virtual reality; hybridisation; input variables

Editor: Dimitrios Panagiotidis

\section{Introduction}

Current forestry is marked by global climatic and socioeconomic changes. Climate change reflected by increased weather variability and more frequent occurrence of extreme events (disturbances) causes changes in forest production, structure, and health (Seidl et al. 2017). Socio-economic changes affect the use of forests towards the expansion of ecosystem services. Planning of forest management now concerns a wider range of interest groups (state, forest owners, non-governmental organisations, and the public). Forest management is not only geared to wood production but also to carbon sequestration, which helps to reduce the rate of climate change, to biodiversity promotion as it increases the resilience and sustainability of ecosystems, as well as to improved quality of people's lives by protecting water and land, by enhancing the recreational function of forests, etc. These changes have a global cross-border character. This requires changing planning procedures and tools, as planning at such a scale is not possible without a tool for predicting forest development.

Yield tables have been frequently used for forest management planning purposes. However, they are currently not able to fully satisfy demands due to the following reasons. Yield tables are intended for even-aged mono- species stands managed using a pre-defined approach and site classification typical for a specific country/region (Assmann \& Franz 1963). They provide only a limited range of applications due to: i) differential management aiming at the preference of mixed, uneven-aged and spatially structured forest stands, ii) diversification of treatments (for example thinning) to regulate ecosystem services, iii) response to climate change and forest disturbances, iv) needs for a diversified range of outputs. Forest inventories based on new technologies, such as terrestrial and aerial laser scanning, terrestrial and aerial photogrammetry, field GIS mapping, unmanned vehicle applications, remote sensing methods, have recently been developed (Liang et al. 2016; Mohan et al. 2017; Puliti et al. 2017). Modern approaches provide a range of data that far exceeds inputs to yield tables and shifts planning opportunities towards precise forestry (treelevel planning). This necessarily involves the need for corresponding forest models. Presented study is concentrated on the review of existing forest model categories, and their potential to solve different planning issues regarding their modelling scale. In the second part, we analyse forest visualisation methods and tools as effective expansions of forest models for interpretation of forest development. 


\section{Current status in forest modelling and visualisation}

\subsection{Variables and parameters of forest models}

Forest models are applied to forests of interests by forest simulators. Forest simulators reproduce the behaviour of forest ecosystems in the form of a computer program (Fabrika \& Pretzsch 2013). Figure 1 shows a scheme of a simulator. A simulator is a unification of the system environment and the system itself described by the model. The system reacts to the environment and influences it in return. The model contains system parameters. System parameters are constant values which control the model. They include various equation coefficients or ecophysiological constants derived from empirical measurements or biological studies. They do not change during a simulation and remain constant even if the simulated object changes, e.g. the forest stand. The current status of the system is described by state variables. State variables change during a simulation and represent main variables of the system. They are input system variables since they describe the initial state of the system, and at the same time, they are output variables because they describe its development. For example, they define tree dimensions or stand variables. A change of state variables is influenced by the model which is controlled by its system parameters. At the same time, the development of state variables also reacts to exogenous and intermediary variables. Exogenous and intermediary variables express the state of the system environment, e.g. climate. Whilst exogenous variables are not influenced by the system, intermediary variables change depending upon the system state. Exogenous variables are therefore related more to the macroclimate (temperature, precipitation), and intermediary variables are more related to the microclimate (light in the stand). Exogenous variables control the model and intermediary variables regulate the model. We can therefore state that the model reacts to the environment (exogenous and intermediary variables), changes the system state (state variables) or in return, the system influences the environment (intermediary variables). The environment controls the system dynamics via exogenous variables and regulates the system state via intermediary variables.

\subsection{Classification of forest models}

Current literature provides a wide selection of models, which vary not only in their principles and algorithms, but also in their software design. The basic classification of models based upon the modelling concept (Kurth 1994) distinguishes empirical, process-based and structural models. Other approaches classify models according to their temporal-spatial hierarchical level (Pretzsch 2001), object-spatial hierarchical level (Lischke 2001), or other principles (see e.g. Munro 1974; Shugart 1984; Vanclay 1994; Liu \& Ashton 1998; Houllier 1995; Franc et al. 2000; Porte \& Bartelink 2002; Pretzsch 2009). The description of the character of individual classifications can be found in monographs dealing with forest modelling, e.g. Pretzsch (2009); Weiskittel (2011); Burkhart \& Tomé (2012) or Fabrika \& Pretzsch (2013).

For this study we chose the classification of Lischke (2001), which was modified by Fabrika \& Pretzsch (2013) and subsequently simplified to its current form (Fig. 2). According to this classification, models can be divided into categories based on several aspects:

a) A concept of forest modelling can be empirical, process-based or structural. Empirical models use statistical relationships (such as regression equations) derived from data gathered at inventory or research plots. The principle of a representative sample is applied, and the models are then generalised

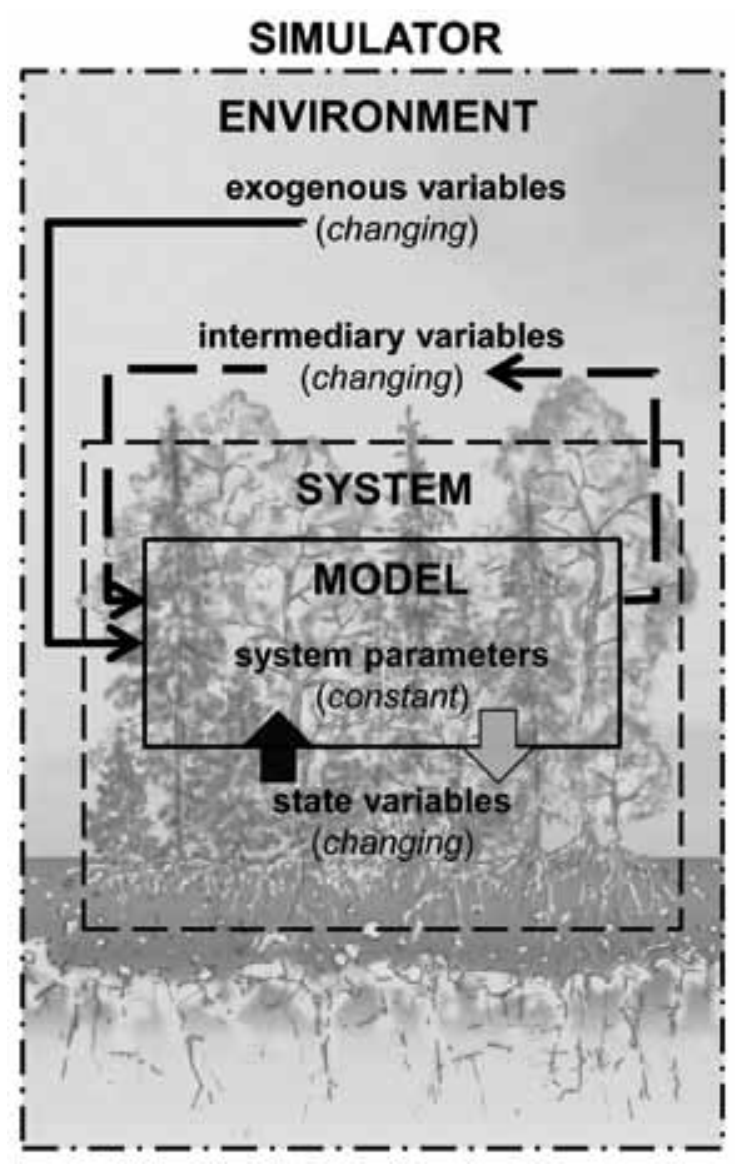

Fig. 1. A simulator, its variables and parameters. The model is controlled by system parameters. It reacts to the surrounding environment (exogenous and intermediary variables), changes the system state (state variables) or in return, it influences the environment (intermediary variables). The environment controls the system dynamics via exogenous variables and regulates the system state via intermediary variables. The black arrows indicate the inputs into the model and the grey arrow indicates the output from the model. The solid thin arrow represents the control of the model and the dashed arrows show the regulation of the model. The thick arrows change the system state (processed by Fabrika \& Pretzsch 2013, page 196). 
for the statistical population the sample represented. Process-based models utilise algorithms that exploit causal relationships known from eco-physiological processes (photosynthesis, respiration, allocation, etc.). They are more general. Structural models predict development of tree morphology, such as a stem, branches, foliage, flowers or fruits. They use, e.g. the principles of fractal geometry, growth grammar and computer graphics.

b) An object of forest modelling may be oriented to organs (e.g. leaves), organisms (e.g. trees), classes/ cohorts (e.g. diameter classes), populations (e.g. forest stands) or ecosystems (e.g. biomes). An object is the principal modelling element represented by state variables that describe its state and change in time. For example, if the modelled object is a tree, it is represented by its diameter, height and volume, while if the object is a forest, its state variables are mean diameter, mean height and growing stock (volume) per hectare.

c) Space of the forest modelling may be represented by a 3D position, 2D position, bio-group, stand, or a region. It specifies in which spatial unit the environment, i.e. exogenous and intermediate variables, changes. The environment refers to the conditions that affect the spatial dynamics of a modelling object, such as the amount of light, climatic conditions, soil conditions, or the competitive pressure. They may be different in the three-dimensional space $(\mathrm{x}, \mathrm{y}, \mathrm{z})$, or they may change only in the horizontal space $(x, y)$, or from one bio-group to another, from one stand to another stand, or from one region to other region.

d) Time of the forest modelling expresses an elementary time unit, for which the changes of the state of the modelled object are shown. It can be minutes, hours, days, years, 5-year intervals or decades, centuries or millennia.

Figure 2 shows the classification of forest models that considers all above-defined aspects of forest growth modelling (Fabrika \& Pretzsch 2013). Due to its resemblance with chess, we call it a "chessboard of models". It shows 10 well-known categories of forest models:

1) Eco-physiological tree models $(\alpha \mathrm{I})$ simulate causal processes (Landsberg \& Sands 2011). Assimilation in foliage of individual trees is their basic modelled feature. Individual leaves or needles can be modelled as separate objects or more frequently as generalised objects in the form of solids of a tree crown or its layers. The position of these objects in 3D space of a stand is important for the level of radiation absorption calculated using different approaches, e.g. the method of ray-tracing (Brunner 1998). The result of the production is net biomass that is allocated into tree organs. Pfreundt (1988) was the pioneer of the described modelling principle, and Hauhs (Hauhs et al. 1995) was the first person who used this principle for forest modelling and developed TRAGIC model. From newer models we can name e.g. BALANCE model (Grote and Pretzsch 2002; Rötzer et al. 2009).

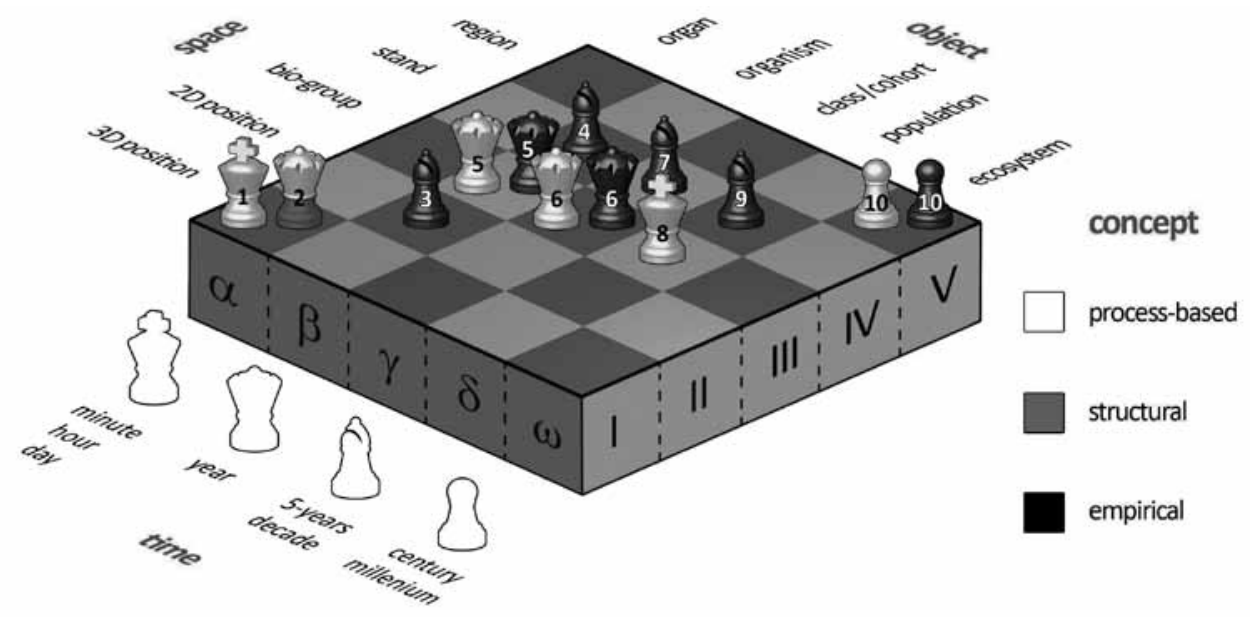

Fig. 2. Classification of models according to object, space, time and concept. Object describes character of state variables changing during simulations. Space describes location of environmental variables (exogenous and/or intemediary) varied in area. Time describes temporal interval for changing of state variables during simulations. Concept describes algorithmic principle of the model. In recent times, the classification has defined 10 categories of models: eco-physiological tree models (1), functionalstructural plant models (2), empirical distance-dependent tree models (3), empirical distance-independent tree models (4), tree gap models (5), cohort gap models (6), distribution models (7), big leaf models (8), stand models (9) and biome models (10). The position on a chessboard classifies a model on the base of a modelling object and spatial resolution. Temporal resolution is expressed by type of the figure. The color defines a dominant concept. Future development may fill other positions of the "model chessboard" (processed by Fabrika \& Pretzsch 2013, page 206). 
2) Functional-structural plant models $(\alpha \mathrm{I})$ deal with modelling the development of plant morphology in time and space. Their foundations were laid by Prusinkiewicz based on the ideas of Lindenmayer (Prusinkiewicz \& Lindenmayer 1990). The models are based on growth grammars (morphemes), which define recurring replacement of tree parts with new parts in a recursive manner. In this way, branching structures (graftals) are created, and are displayed using vector (turtle) graphics. Hence, they originate in the fractal geometry and the so-called L-systems. The shape and the size of new plant structures depend on eco-physiological processes, in particular photosynthesis, which are directly built in growth grammars. As an example, we can name GROGRA (Kurth 1999); LIGNUM (Perttunen et al. 1998) or GroIMP (Kniemeyer 2008) products.

3) Empirical distance-dependent (spatially explicit) tree models ( $\beta$ II) are based on empirical relations between tree increment (on diameter, height or volume), environmental conditions (e.g. site index of a stand, or a set of site conditions), and competition pressure on a tree. Competition pressure is simulated using competition indices dependent on the position and dimensions of the surrounding trees. The foundations of this approach were laid by FOREST model (Ek \& Monserud 1974). From newer models we can mention e.g. SILVA (Pretzsch et al. 2002; Pretzsch 2009) model. 4) Empirical distance-independent (spatially nonexplicit) tree models ( $\beta \mathrm{IV}$ ) are of a similar character but modelling of tree competition is not dependent on tree co-ordinates. The competition pressure is derived using the total area (canopy cover or density) or tree position within the cumulative frequency function of the selected biometric characteristic. This simplified approach of modelling competition was introduced by Wykoff et al. (1982) in the STAND PROGNOSIS MODEL. From later models we can mention PROGNAUS (Sterba 1995) or BWIN (Nagel 1996).

5) Tree gap models ( $\beta$ III) divide the area of interest into bio-groups of trees (generally covering from 100 to $1,000 \mathrm{~m}^{2}$ ). They focus on modelling the growth of individual trees in bio-groups. Biometric characteristics of trees (e.g. diameter, height) in groups are known. Tree positions are not taken into account, but the positions of bio-groups within the stand are important because they determine the dynamics of the vegetation (succession) in the modelled forest. From the pioneers of this modelling principle we can name Botkin et al. (1972) and their JABOWA model, or FORET model by Shugart \& West (1977). From newer products we can mention e.g. PICUS (Lexer \& Hoenninger 2001).

6) Cohort gap models ( $\gamma \mathrm{III})$ assume that trees in bio-groups are divided into so called cohorts, which represent generations of trees characterised by distinctive heights. Every cohort is represented by a mean tree and the number of trees. Only the growth of a typical tree representing a specific cohort is simulated, which saves computing time without a significant impact on simulation results. During simulations, trees do not change their memberships in cohorts. Hence, tree number in a specific cohort can only be reduced due to mortality. A model of this category was first created by Bugmann (1994), who proved that the trees similar in size at the beginning of the simulation remain similar during their entire lives. Bugmann applied this approach in his model called ForClim (Bugmann 1996).

7) Distribution models $(\gamma \mathrm{IV})$ simulate forest growth dynamics on the base of frequency dynamics of a selected biometric parameter. In this category of models, an entire forest stand is divided into classes of a specific characteristic, e.g. diameter. Classes do not change in time, but trees change respective classes as they grow. This differentiates these models from the previous group, where cohorts act as classes, the size of which can change, but the membership of trees in cohorts remains constant. The simplest way of modelling is changing the frequency function during time by modifying parameters (Clutter 1963; von Gadow 1987). Other possibilities are to use distribution models based on differential equations (Moser 1974), or Markov Decision Process models (MDP, e.g. Sloboda 1976; Suzuki 1971; Buongiorno 2001).

8) Big leaf models ( $\delta I I I)$ generalise assimilation organs in the form of an abstract leaf, which represents the whole spatial unit of an ecosystem, e.g. $1 \mathrm{~m}^{3}$. The assimilation of an abstract leaf is identical to the performance of a modelled population in a spatial unit. These models assume that the spatial unit is homogeneous from the point of its tree crown cover and represents a certain type of vegetation. Radiation absorption is solved on the basis of leaf area index of the homogeneous crown cover, e.g. using Lambert-Beer law that is sometimes combined with Campbell method of ellipsoid orientation of assimilation organs (Campbell 1986, 1990). The basic representatives of this category are models 3-PG (Landsberg $\&$ Waring 1997) or Biome-BGC (Thornton 1995).

9) Stand models ( $\delta I V)$ represent most traditional models that represent the entire population or a species in a forest stand. They simulate the development of mean tree and stand parameters (e.g. mean diameter, mean height, growing stock) on the base of a site index. They are derived exclusively from empirical regression models that are frequently based on growth functions. Their beginnings go back to yield tables (Assmann \& Franz 1963; Hamilton \& Christie 1973; Vuokila 1966; Schmidt 1971; Lembcke et al. 1975; Halaj et al. 1987). These models have a limited validity for a specific stand type, stand density, and forest management regime. More flexible models of this type are STAOET (Franz 1968) and DFIT (Bruce et al. 1977).

10) Biome models $(\omega V)$ assume that the occurrence of vegetation types (biomes) depends on environmental conditions (e.g. temperature and precipitation). They deal with changes of climax vegetation types over long time periods (centuries to millennia). The first and nowa- 
days the classical representative is the model by Holdridge (1947). From newer models we can mention e.g. BIOME (Prentice et al. 1992) or DOLY (Woodward \& Smith 1994).

The 10 above-mentioned categories of models can be considered as the basis, from which further possible modifications can be derived. The position of the type in the classifications is marked with their typical position, some variations may however occur outside their typical position. The same is true for the colours of marks in the classification, which represent the modelling concept. In the classification we chose the prevailing concept for a given type of models (Fig. 2). However, model categories may also use other concepts.

The current trend in modelling is hybridisation. Hybrid models combine several categories of models. They are mutually complementary, i.e. their algorithms are mutually bound. Another trend is to use downscale or upscale procedures, which enable shifts from a more general modelling level to a more detailed level (downscale) or vice versa from a more detailed level to a more general level (upscale) using a serial approach. The second procedure is more frequent (seeworks by King 1991; Rastetter et al. 1992; Bugmann et al. 2000; Dieckmann et al. 2000, Auger \& Lett 2003; Urban 2005; Lischke et al. 2006). In addition, a parallel approach of a multi-scaling type can also be applied, when one product uses several types of mutually unbound models in parallel, which are selected depending on the purpose of simulations, as it is e.g. in the current version of SIBYLA model (http:// sibyla.tuzvo.sk).

The presented model classification is not only versatile, but also open. This means that, if in science or practice the need for a new category of models is identified, a new position of a given colour mark can be put on a particular square of the classification. A similar principle has been applied for the current development of forest models. For example, the first position ( $\delta I V)$ was filled with yield tables and so far, the last position $(\alpha \mathrm{I})$ was occupied with eco-physiological tree models and functional-structural plant models.

We reviewed 34 models from the point of the applied concept, modelled object and space, and used temporal resolution. We found that currently the majority of models combine approaches, i.e. they use different concepts for modelling different processes and simulate different processes at different spatial and temporal scales. This indicates that most current models are hybrid. Therefore, when applying the classification presented above (Fig. 2) we focused on biomass production to enable inter-model comparison. As can be seen from Table 1, most reviewed models (67\%) utilise a process-based modelling concept, while the empirical concept was used only in 9 models (26\%), and the structural concept in 2 models (6\%). Although the selection of models was not performed systematically but was influenced by authors' knowledge and experience in forest growth modelling, we assume that the distribution of the models in individual concepts reflects the actual state in modelling forest growth.

From the point of the modelled object, in the reviewed models we identified all levels presented in Fig. 2, although the frequencies were unevenly distributed. The levels of an individual tree and a class/cohort were most frequently used (each in $35 \%$ of reviewed models), while an organ or an ecosystem were used least often (only in 3 models each).

Similarly, we found all spatial resolutions identified in Fig. 2 that were unevenly represented in the group of reviewed models. The majority of models (41\%) operate at a stand scale, followed by a bio-group, which was a characteristic spatial resolution in $35 \%$ of models (Table $1)$. The level of a region was used only in one model, and the positions of individuals in 2D or 3D space were included in 4 and 3 models, respectively.

We found that a class versus a bio-group (position $\gamma$ III in Fig. 2) was the most frequent combination of an object and space used in nine reviewed models (26\%). This combination represents cohort models (Fig. 2). When examining these nine models more closely we found out that the majority of them operate at grid cells, i.e. they are often used for landscape modelling. These models simulate different processes at different temporal and spatial levels, often including interactions between individual cells.

From the temporal point of view, the shortest identified time step was one minute and the longest was 5 years, while a day was the most prevailing time step applied in 11 models (Table 1). Some models operate at multiple time scales depending on the process they simulate, e.g. ANAFORE (Deckmyn et al. 2008) or iLand (Seidl et al. 2012).

Applied dimensions of the classification specify the conditions under which the usage of models is suitable. For example, models operating at long time steps are not able to capture intra-annual changes. Thus, they are not suitable for short-term studies of e.g. extreme climate events, such as drought. Inter-tree competition can only be considered in the models simulating individual trees in a forest stand. Models operating at a coarser spatial resolution can provide us with the information about the forest as a whole, but are not able to describe the specific development of every tree with regard to its surrounding. The applicability of each model in a specific situation depends also on other model characteristics that were not discussed here, mainly on what processes are simulated with the model and what approaches are used for their simulations.

\subsection{Classification of methods and tools for forest visualisation}

Several authors have addressed the issue of classifying techniques and approaches in forest visualisation 
Table 1. List of reviewed models.

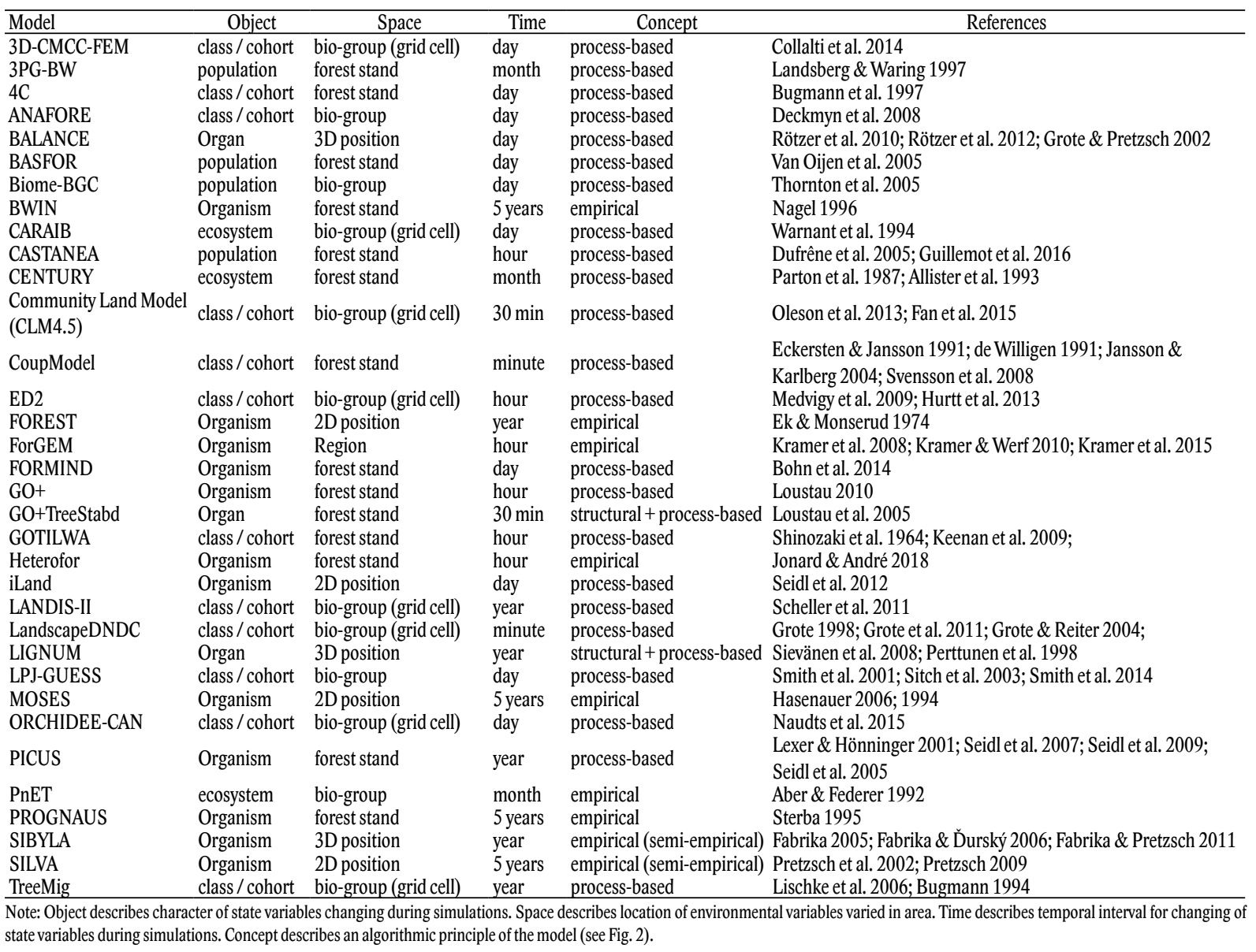

(e.g. Orland 1992, 1997; McGaughey 1997; Buckley et al. 1998; Karjalainen \& Tyrväinen 2002; Fabrika \& Durský 2005; Pretzsch et al. 2007). Over the last 20 years, significant progress in visualisation methods has been achieved. Today several visualisation techniques are available (Fig. 3). Trees and stands can be displayed in the form of geometric models (1) as horizontal projections (1a), vertical profiles (1b), three-dimensional projections (1c), rendered scenes (1d), or in the form of virtual reality (1e). Another possibility is to use billboard models (2). They represent approaches, when an image of a tree or other forest objects is projected onto a plane surface. The surface can be simple (single-panel models, $2 \mathrm{a}$ ) or composite (multi-panel models, 2b). Images are most frequently in the form of textures with transparent background, and panels can be interactively rotated towards the observer. Another alternative is to use photographic models (3), which faithfully display forest reality. They can be implemented as snapshot models (3a), sightseeing models (3b), or virtual tours (3c). Forest visualisation uses different methods depending on the scale (Fig. 3). Models can represent a plot (I), a stand (II), or landscape (III). The selection of the scale depends on the chosen detail. A more detailed description of visualisation methods can be found in Fabrika \& Pretzsch (2013).
Intensive development of information technologies in recent decades has created conditions for the development of still smarter visualisation hardware. These devices are aimed not only at improving the optical perception of a user, but they also develop new ways of interaction with a virtual environment and address the issues of recording user's motion transferred to virtual reality. Important technological characteristics of modern visualisation tools are presented in Fig. 4. According to used projection methods (A), systems can be cubic (A1), cylindrical (A2), spherical (A3), or planar (A4). Depending upon used projection technologies (B), systems are divided into those realised through projectors (B1), displays (B2) or HMD equipment (B3). According to the character of perception (C), systems can either be with (C1) or without (C2) stereoscopic perception. From the point of immersion level (D), systems can be with partial (D1) or full (D2) immersion. Considering movement in virtual reality $(\mathrm{E})$, systems can be based on devices (E1) or on natural movement (E2). Based on the number of users (F), systems can be created for one (F1) or more (F2) users. Hence, the final solution is given by a combination of various aspects. Currently, a number of different solutions are available, e.g. CAVE systems (Cruz-Neira et al. 1993; Defanti et al. 2009) [A1 + B1 + C1/C2 + D1 + E2 + F2], CAVE2 systems (Febretti et al. 


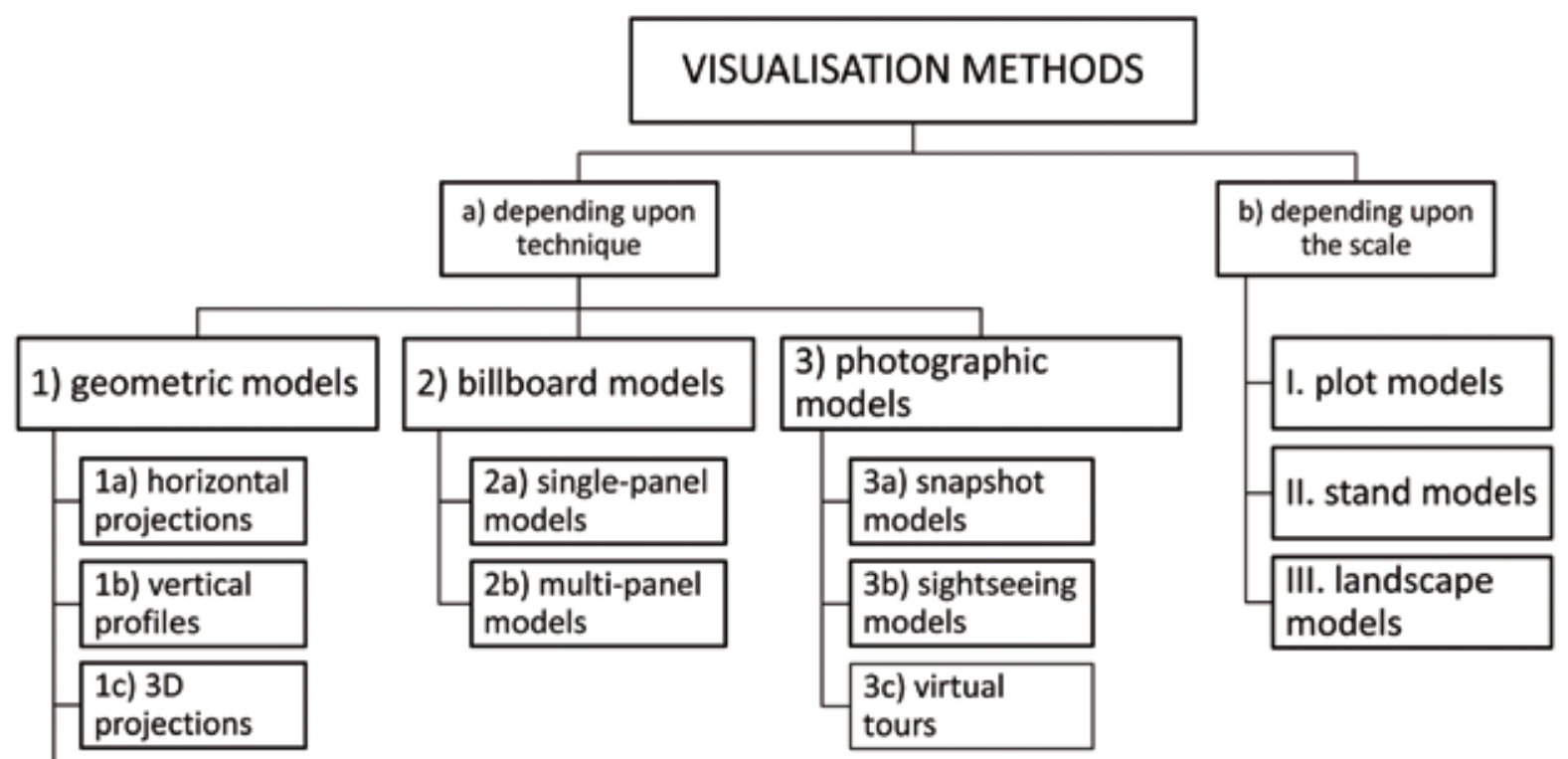

1d) rendered scenes

1e) virtual reality

Fig. 3. Classification of forest visualisation methods according to: (a) techniques, (b) scale.

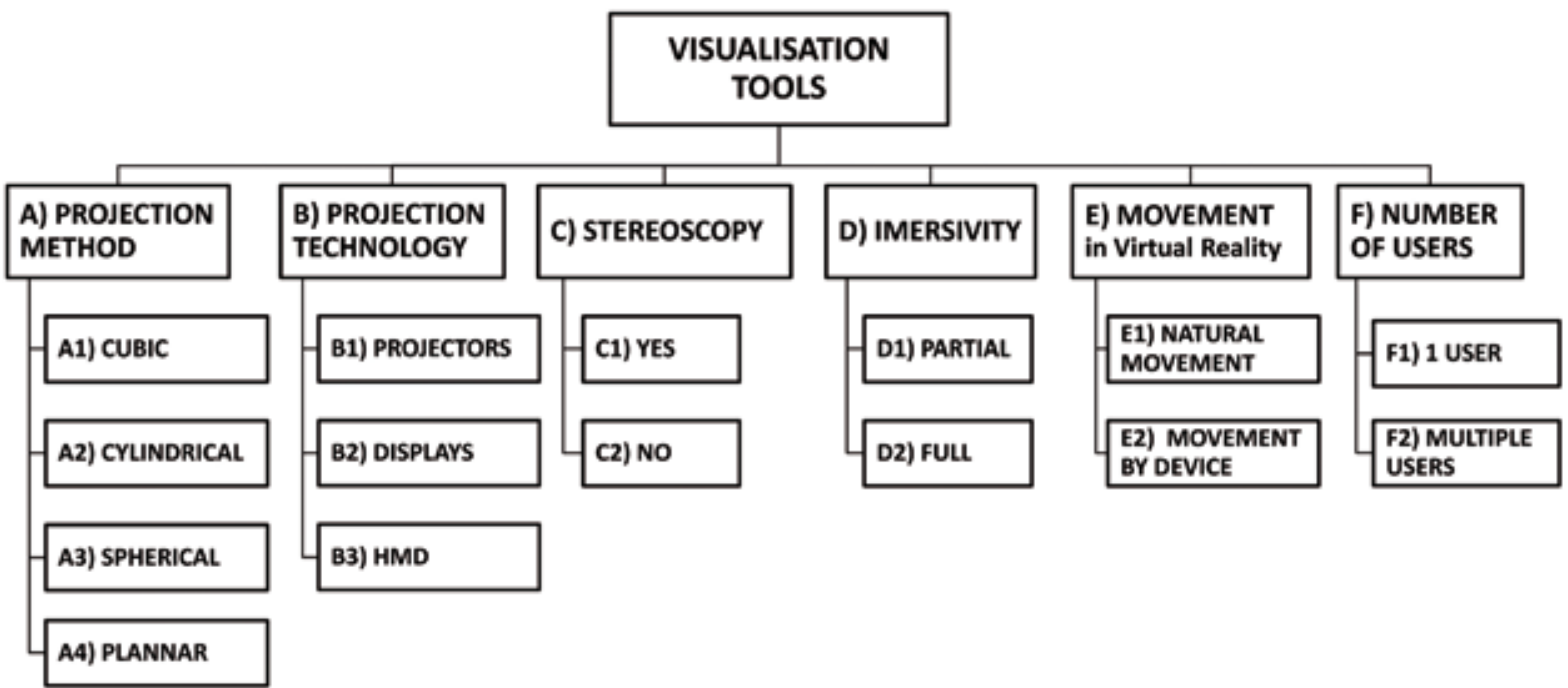

Fig. 4. Categorisation of hardware tools used for forest visualisation on the basis of their technological solutions.

2013) $[\mathrm{A} 2+\mathrm{B} 2+\mathrm{C} 1 / \mathrm{C} 2+\mathrm{D} 1+\mathrm{E} 2+\mathrm{F} 2]$, HMD systems - Head mounted display (Oculus 2017) [A4 + B3 + C1 + $\mathrm{D} 2+\mathrm{E} 1 / \mathrm{E} 2+\mathrm{F} 1]$, and Virtusphere (Virtusphere 2017) or Cybersphere systems (Fernandes et al. 2003) [A3 + $\mathrm{B} 1 / \mathrm{B} 3+\mathrm{C} 2 / \mathrm{C} 1+\mathrm{D} 1 / \mathrm{D} 2+\mathrm{E} 1+\mathrm{F} 1]$. To simulate natural movement of a user, various specialised systems are nowadays used, e.g. Cyberith Virtualizer (Cyberith 2017) or Virtuix Omni (2017). For tracking user's position, optical cameras (e.g. Vicon Bonita 2017) or magnetic sensors (e.g. Polhemus 2017) are most frequently used.
2.4. Tools for generating, reproduction and reconstruction of missing or unknown input variables

As the modelling detail increases, the set of input data also increases. Considering temporal, economic, methodological and technological limits for the acquisition of input data, models often comprise auxiliary tools, which derive more detailed input from commonly available or more general data. This saves time and costs even if it is at the expense of output accuracy. With this 


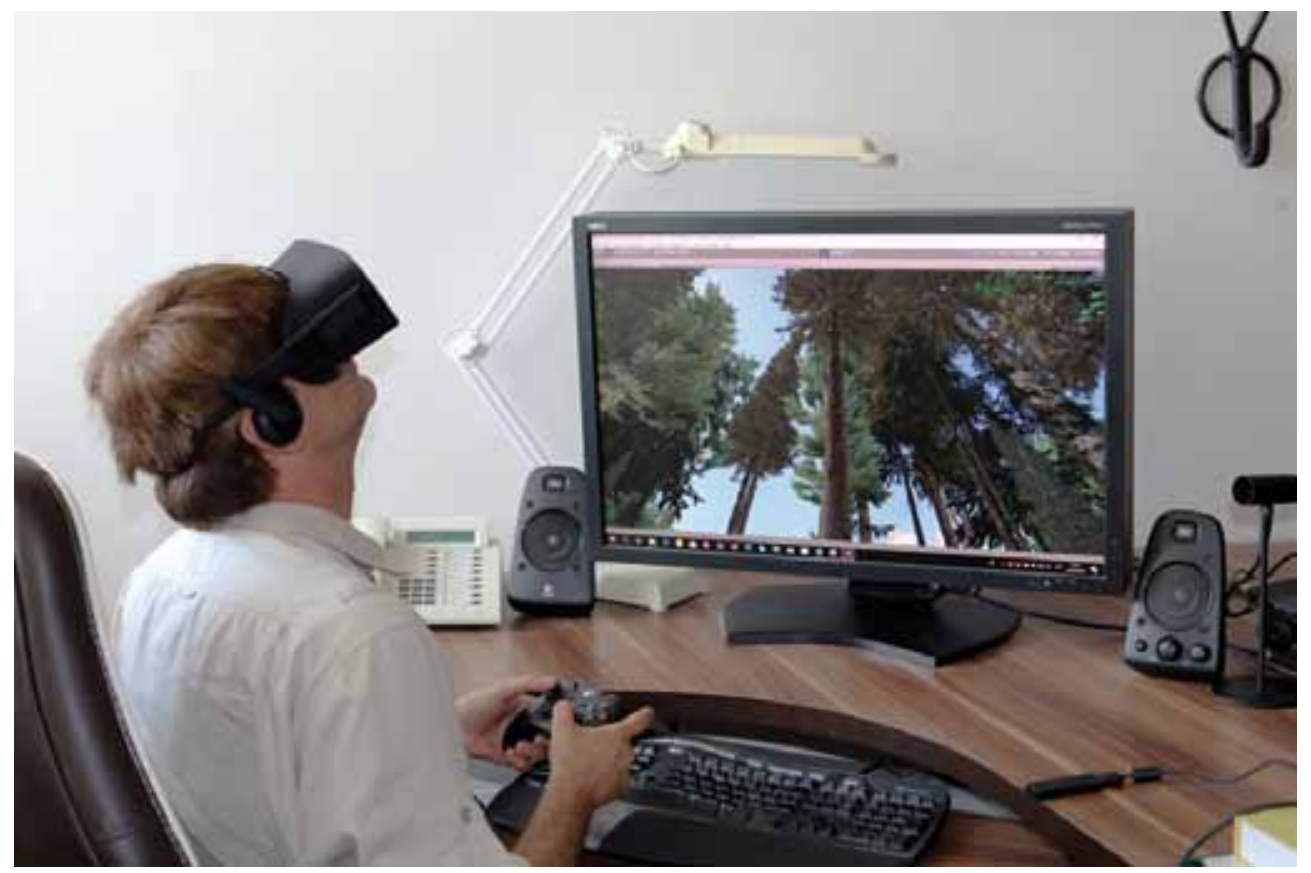

Fig. 5. Example of forest visualisation via OCULUS Rift device (photo: Peter Valent, 2017).

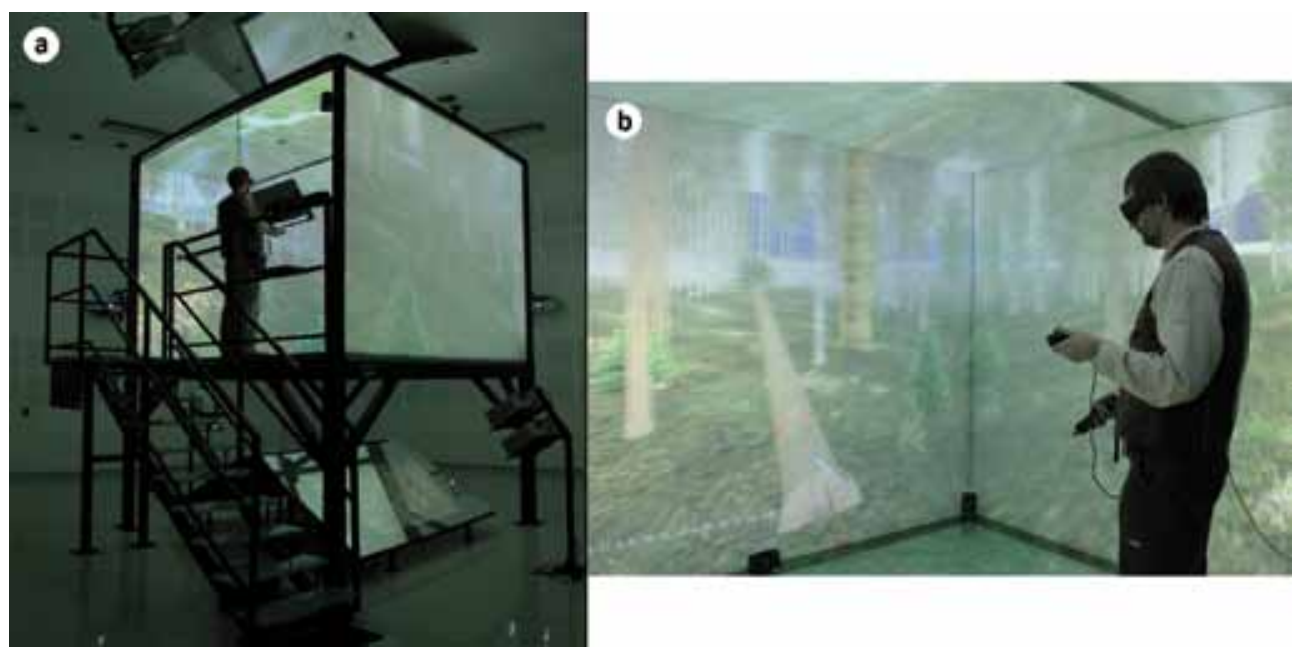

Fig. 6. Example of CAVE device (a) and visualisation of a virtual forest stand with tree interaction (b) (photo: Peter Valent, 2017)

approach we can also derive missing or unknown data necessary for forest modelling with a selected model type (Fig. 2). As an example, we can name various interfaces for forest inventories, tools for structure reconstruction and reproduction, structure generators, site generators, weather generators or models for the numerical weather prediction (Fig. 7).

An interface bound to forest inventory outputs contains various computer procedures and algorithms, which can provide or derive necessary data from available inventory databases or geographic information layers.

Tools for structure reconstruction are connected to special methods of field data collection, such as field GIS sets (Černý \& Bukša 2005), terrestrial laser scanning (Simonse et al. 2003; Aschoff et al. 2004; Heurich et al. 2004; Hopkinson et al. 2004; Pfeifer et al. 2004; Bienert \& Scheller 2008; Klemmt \& Tauber 2008; Koreň et al. 2017) or remote sensing methods, e.g. aerial photogrammetry (Gougeon 1995; Dralle \& Rudemo 1997; Brandtberg 1999, 2002; Gitelson et al. 2002; Surový et al.2004), aerial laser scanning (Magnussen \& Boudewyn 1998; Harding et al. 2001; Persson et al. 2002; Popescu et al. 2002; Heurich et al. 2003; Lim et al. 2003; Blaschke et al. 2004; Clark et al. 2004; Holmgren \& Persson 2004), etc. The aim of these procedures is to derive (reconstruct) parameters of objects from obtained data layers or survey materials, e.g. to derive the position of trees or their biometric parameters (diameter, height, crown parameters), or for some types of models to reconstruct the morphology of stems or tree crowns. 


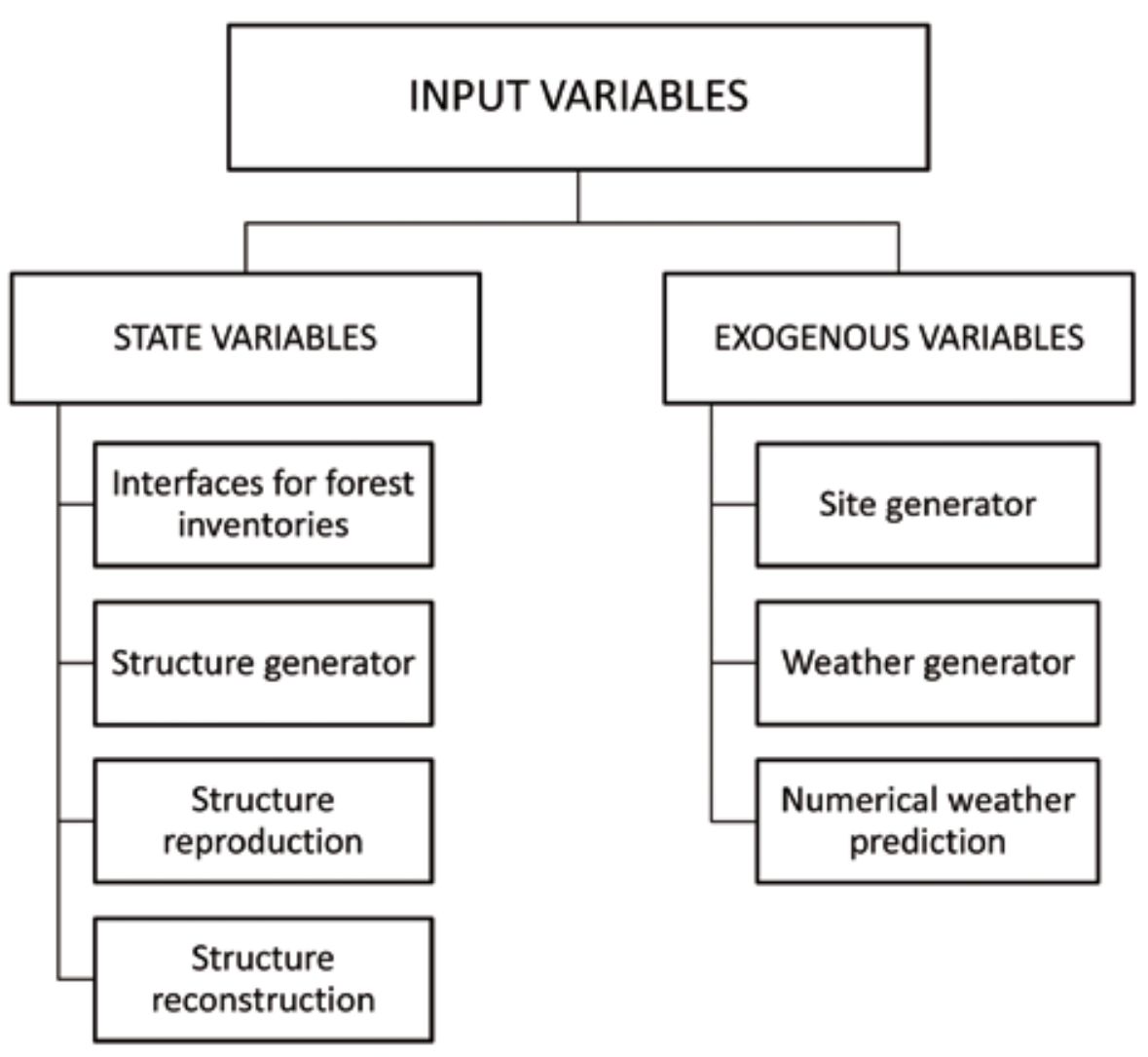

Fig. 7. Tools for deriving more detailed input data for forest growth models from commonly available or more general data.

Forest structure generators were developed in order to generate more detailed data from more general data, e.g. to generate tree diameters, tree heights, crown parameters and position of trees from the information about mean diameter, mean height and growing stock, or stand basal area. For structure generation, the methodologically proved approaches (Nagel \& Biging 1995; Merganič \& Sterba 2006), which ensure that the values of more general input data remain the same, are used. At the same time, they create a structure, which by its nature suitably represents the modelled stand. Some algorithms even account for the pattern and proportion of the species mixture (Pretzsch 1997).

Tools for forest structure reproduction represent a specific category derived from the tools used for structure reconstruction and structure generators, since they are used to generate an unknown forest structure outside inventory plots on the basis of the known structure at inventory plots (Pommerening 1999; Pommerening et al. 2000). It means that a part of a forest represents the actual situation at inventory plots, and a part is filled in by structure generators. Reproduction is used to create so-called representative stands.

Site generators are used to derive the data on site conditions, which are not available from usual information sources. They are used in models that require average or aggregate climatic characteristics as input for model- ling the intensity of growth processes. An example of such situations is modelling of tree increments (effect) on the base of the value of a site variable (dose) and cumulating of effects caused by multiple site variables (Kahn 1994). Site generators derive required variables on the base of the commonly available data, e.g. geographical coordinates or a forest region, elevation, aspect and slope of the terrain, etc. Different approaches are used, e.g. climate regionalisation using geo-informatic procedures (Fabrika et al. 2005).

Weather generators are used primarily in processbased models that require information on weather characteristics for short time periods, e.g. hours or days. Due to frequent unavailability of such data, they are generated using models, which the average or aggregate meteorological data representing a longer period, usually a year or a growing season, distribute to individual months, days or hours. Algorithms are commonly based on statistical approaches. At present there are many models of this nature. As examples we can name WGEN (Richardson \& Wright 1984), SIMMETEO (Geng et al. 1986, 1988), TAMSIM (McCaskill 1990), CLIMGEN (Clemence 1997), MET\&ROLL (Dubrovský 1997), LARSWG (Semenov et al. 1998), AAFC-WG (Hayhoe 2000), MARKSIM (Jones \& Thornton 2000), RUNEOLE (Adelard et al. 2000), WM2 (Hansen \& Mavromatis 2001) or CLIMA (Donatelli et al. 2009). 
Models of numerical weather prediction are used everywhere, where scenarios of temporal development of climatic characteristics are required for simulations of future forest production. They are mostly models of atmospheric physics that use quantitative methods for simulating interactions between atmosphere, oceans, earth's surface and ice. These models are very complex and demanding for computing power. Therefore, supercomputers or other technologies of high-performance computer processing of data are frequently used. In Europe, ALADIN (Huth et al. 2003) is a well-known and frequently used model.

\section{Perspectives of forest models and visualisation}

\subsection{Vision on future development of forest modelling}

The development of forest models is currently very significant. Among the many important perspectives and challenges of further development, the following can be mentioned:

a) Hybridisation of models. Specific model types are associated with specific applications. No model type is universal for all problems. Each one is suitable for a certain type of tasks. Therefore, the versatility of models is often addressed by the hybridisation of approaches (Kimmins et al. 2010), e.g. by a combination of an empirical concept with a process-based one. Model hybridisation extends the scale of model usage.

b) Downscaling, upscaling, multiscaling. Each model type is focused on a particular type of objects (Fig. 2). However, tasks to be solved often exceed the framework of one type of the modelled object. It ranges from the organ through the tree and population to the landscape. Therefore, it is necessary to choose a so-called core model from which more generalised objects are modelled by upscaling and more detailed objects by downscaling (Aertsen et al. 2012). This is a serial approach to forest modelling when the outputs of core models are used as inputs in subsequent models, namely forward sequence (upscale) or reverse sequence (downscale). It is also possible to use multiscaling parallel approaches, when multiple object types are modelled at the same time using multiple types of models and the resulting outputs are combined in the required way.

c) Development of process-based models. Climate change requires models that are more sensitive to environmental factors in planning. Process-based models are more suitable for these purposes than empirical models because they use causal relationships between environmental factors and growth instead of regression relationships. Hence, they can also capture growth responses that are beyond the growth reactions known from the present. Regression relationships are valid only for the population, from which the sample was taken and only for the period, in which the values of the environmental factors were valid. Outside these ranges, the prognoses do not have to capture the real behaviour of the forest since regression models extrapolate the performance beyond the data limits.

d) Quantification of ecosystem services. Forest policy changes because of pressures from society and thus the target ecosystem services are also changing. There are increasing demands to quantify ecosystem services using basic or auxiliary variables, resp. linking functions (Biber et al. 2015). This is a complex issue given that the assessment of some ecosystem services is very complex or based on subjective or aesthetic principles. Hence, their quantification does not always correlate with basic or auxiliary variables that are the output of the models.

e) Open software solutions and shells. Alarge number of prognostic tools nowadays exist. Therefore, efforts are made to unify the environment to enable the use of heterogeneous models or the integration of the program interface to connect various algorithms of models, so called shells. A good example is CAPSIS tool (Dufour-Kowalski et al. 2012).

f) Interfaces to sophisticated data collection methods. Many of the models, especially those that work with higher details such as organs or trees, require a large set of input data. Therefore, methodologies linked to forms of collecting detailed data, such as point clouds derived from terrestrial laser scanning (Liang et al. 2016) or close-range photogrammetry (Mikita et al. 2016; Mokroš et al. 2018a, b), have been developing over the last years.

g) Application of precision forestry methods. Recently, operational, tactical and strategic planning methods have been developing very intensively. They are closely connected with tools to predict forest development. As new inventory methods working with tree-level detail (parameters and positions) and prognostic tools with adequate modelling detail have become available, the so-called precision forestry method (Fox et al. 2008) has been implemented in the planning.

h) Development and use of decision support systems (DSS). The principles of flexibility and planning adaptability require prognoses for multiple scenarios of climate development, economic development, forest management variants, etc. Simulating all variants and/or scenarios produces extensive databases that need to be processed and evaluated. Decision support systems (Sodtke et al. 2004) are used to analyse the results of the prognoses. They are based on different procedures such as mathematical programming, knowledge-based and expert systems, neural networks, datamining methods, etc. Their goal is to 
select the most suitable forest management variant in relation to the chosen scenarios and a set of objectives (target ecosystem services). It is clear from the nature of the problem that these are multi-criteria forms of decision making.

\subsection{Expected progress in forest visualisation}

The need for communication with the public and easier interpretation of simulation results requires the development of forest visualisation tools. Several issues need to be addressed from this persepctive, such as linking forest landscape generators to forest inventory data and geographic information systems, use of high-quality 3D models for objects (organs, trees, plants, etc.), game engine integration, physical model implementation (shadows, wind movements, weather, etc.), the use of modern hardware tools to display virtual reality (HMD, CAVE). Such tools enable that the prognosis results are available in the form of a virtual forest or virtual forest landscape.

Immersion is a very important property of visualisation. Immersion can be achieved with specialised hardware. Some authors have tried to implement immersion in the easiest and cheapest way using the HMD devices, e.g. Oculus Rift (Oculus 2017). Although such a solution provides a fully immersive experience, is affordable and space-undemanding, it is limited to a single user. The possibilities of the cooperative mode with multiple users were resolved with the devices of the CAVE type (CruzNeira et al. 1992).

Many of the CAVE systems are prototypes that meet specific requirements. According to the visualisation purposes, they are built in various configurations of projection walls (DeFanti et al. 2011). They can either consist of one front, two side walls and a floor, as it was in the case of the first CAVE system (Cruz-Neira et al. 1993), or the user can be completely surrounded by the projection, as it is in e.g. 5-wall StarCAVE (DeFanti et al. 2009), or 6-wall CAVE systems such as Cornea (Cornea 2017), C-6 in Iowa (VRAC 2008), etc.

CAVE systems are based on the back-projection at the projection walls with the projectors, although more modern devices employing screens instead of projection walls are also built. Such a system was constructed by a team of EVL scientists and is known as CAVE2 (Febretti et al.2013), which indirectly indicates the second generation of the systems. They also often exist in the form of mobile display panels consisting only of several screens such as NextCAVE (Merrill 2009). Using screens for the visualisation deals with the requirements on high resolution and contrast compared to systems based on projectors, but construction of such systems completely surrounding the user is still a major technological challenge (DeFanti et al. 2011). One problem is, for example, separation of the screens through their frames and a more difficult production of a stereoscopic image with regard to the number and configuration of displays.

Another important aspect of visualisation is the movement in virtual reality. The simplest approach is the movement with various control devices in user's hands. However, this is often not sufficient for a complex experience, especially in the case of the trainers working directly with man's movement. This shortcoming was eliminated by the developers of the systems such as Virtusphere (Virtusphere 2017) or Cybersphere (Fernandes et al. 2003) that are based on the natural movement of the user inside the polycarbonate sphere which rolls over the system of bearings affixed to a firm base. This system is not compatible with the equipment of the CAVE type, because it is a different technological solution. The image is either projected into a helmet of the HMD type, or at the sphere itself with back-projection but without the stereoscopic character. The systems can be used by a single user only, because the movement of more persons in one sphere is problematic, if not dangerous. Developers of other devices, e.g. Virtuix Omni (Virtuix 2017) or Cyberith Virtualizer (Cyberith 2017), also deal with the possibilities to use the natural forms of movement. These are independent technological solutions that are based on the principle of user movement on a special pad. The pad is equipped with sensors that record movement and transform it into virtual reality. This fact opens possibilities of mutual integration of these devices with other systems such as the HMD or CAVE systems.

However, hardware is not the only thing that is important for the quality, interactivity and immensity of forest visualisation. Software solutions are also important. In the past, specialised programs using simple objects and support libraries (OpenGL, DirectX) and languages (VRML97, X3D) were frequently used, while today more complex Game Engines based environments (Unity 3D, Unreal Engine, CryEngine) are applied. These environments take full advantage of today's graphics cards and support physical processes (light propagation, shadow casting, wind movements, refraction of light on particles in the air, surface mirroring, light reflections from objects, gravity on objects, etc.). The future of visualisation lies in the massive deployment of Game Engines, their integration with specialised hardware (HMD, CAVE) and the transition from the visualisation of smaller forest areas to the visualisation of whole forest landscapes.

\section{Conclusion}

Forest models are based on a wide variety of different approaches that are used for their construction. This variety reflects the needs of the forestry community for specific parameters to be calculated. The number of specific tasks that need to be solved with forest models has increased since the beginning of model development. Frequently, the tasks are very complex and thus can only 
partially be solved by specific models. Hybridisation or scaling of forest models are possible approaches to solve this issue. Defined model classification and description helps users in fast orientation and selection of appropriate models for specific application. An overview of visualisation tools provides us with available possibilities to present complex forest ecosystems, and a wide variety of outputs from models in an easy and understandable way.

\section{Acknowledgements}

This study was supported by the Slovak Research and Development Agency under contracts APVV-0069-12, and APVV-150265, and by the Grant Agency of the Ministry of Education, Science, Research and Sport of the Slovak Republic under contract KEGA 011TUZ-4/2019. KM was also supported by grant “EVA4.0”, No.CZ.02.1.01/0.0/0.0/16_019/0000803financed by OPRDEEVA4.0.

\section{References}

Aber, J. D., Federer, C. A., 1992: A generalized, lumpedparameter model of photosynthesis, evapotranspiration and net primary production in temperate and boreal forest ecosystems. Oecologia, 92:463-474.

Adelard, L., Boyer, H., Garde, F., Gatina, J.-C., 2000: A detailed weather data generator for building simulations. Energy and Buildings, 31:75-88.

Aertsen, W., Kint, V., Muys, B., Van Orshoven, J., 2012: Effects of scale and scaling in predictive modelling of forest site productivity. Environmental Modelling \& Software, 31:19-27.

Allister, K. M., Harding, L. A., Vernon Cole, C., Parton, W. J., 1993: CENTURY Soil Organic Matter Model Environment. Available at: https://www2.nrel. colostate.edu/projects/century/MANUAL/html_ manual/man96.html (accessed 12.8.18).

Aschoff, T., Thies, M., Winterhalder, D., Kretschmer, U., Spiecker, H., 2004: Automatisierte Ableitung von forstlichen Inventurparametern aus terrestrischen Laserscannerdaten. 24. Wissenscgaftlich-Technische ahrestagung der DGPF 2004, Halle/saale, p. 341-348.

Assmann, E., Franz, F., 1963:Vorläufige Fichten-Ertragstafel für Bayern. Institut für Ertragskunde der Forstlichen Forschungsanstalt, München, 104 p.

Auger, P., Lett, C., 2003: Integrative biology: linking levels of organization. Comptes Rendus Biologies, 326:517-522.

Biber, P., Borges, J. G., Moshammer, R., Barreiro, S., Botequim, B., Brodrechtová, Y. et al., 2015: How Sensitive Are Ecosystem Services in European Forest Landscapes to Silvicultural Treatment? Forests, 6:1666-1695.
Bienert, A., Scheller, S. T., 2008: Verfahren zur automatischen Bestimmung von Forstinventurparametern aus terrestrischen Laserscannerpunktwolken. 28. Wissenschaftlisch-Technische Jahrestagung der DGPF, p. 110-120.

Blaschke, T., Tiede, D., Heurich, M., 2004:3D-landscape metrics to modelling forest structure and diversity based on laser-scanning data. In: Thies, M., Koch, B., Spiecker, H.,Weinacker, H. (eds.): Laser Scanners for Forest and Landscape Assessment. Proceedings of the ISPRS Working Group VIII/2. Freiburg, Germany, October 3-6, 2004. International Archives of Photogrammetry, Remote Sensing and Spatial Information Sciences, vol. XXXVI, Part 8/W2, p. 129-132.

Bohn, F. J., Frank, K., Huth, A., 2014.: Of climate and its resulting tree growth: Simulating the productivity of temperate forests. Ecological Modelling, 278:9-17.

Botkin, D. B., Janak, J. F., Wallis, J. R., 1972: Some ecological consequences of a computer model of forest growth. Journal of Ecology, 60:849-872.

Brandtberg, T., 1999: Automatic Individual Tree-Based Analysis of High Spatial Resolution Remotely Sensed Data, Acta Universitatis Agriculturae Sueciae, 16 p.

Brandtberg, T., 2002: Individual tree-based species classification in high spatial resolution aerial images of forests using fuzzy sets. Fuzzy Sets and Systems, 132:371-387.

Bruce, D., Mars, de, D. J., Reukema, D. C., 1977: Douglas-fir managed yield simulator: DFIT User's Guide, USDA, Forest Serv. Gen. Techn. Report PNW-57, PNW Forest and Range Experimental Station, Portland, OR., 2 p.

Brunner, A., 1998: A light model for spatially explicit forest stand models. Forest Ecology and Management, 107:19-46.

Buckley, D. J., Ulbricht, C., Berry, J., 1998: The Virtual Forest: Advanced 3-D Visualization Techniques for Forest Managament and Research. ESRI, Proceedings GIS'98, 15 p.

Bugmann, H. K. M., 1994. On the ecology of mountainous forests in a changing climate: a simulation study (Doctoral Thesis). ETH Zurich.

Bugmann, H., 1996: A simplified forest model to study species composition along climate gradients, Ecology, 77:2055-2074.

Bugmann, H., Grote, R., Lasch, P., Lindner, M., Sukkow, F., 1997: A New Forest Gap Model to Study the Effects of Environmental Change on Forest Structure and Functioning. Impacts of Global Change on Tree Physiology and Forest Ecosystems, p. 255-261.

Bugmann, H., Lindner, M., Lasch, P., Flechsig, M., Ebert, B., Cramer, W., 2000: Scaling issues in forest succession modelling. Climatic Change, 44:265-289. 
Buongiorno, J., 2001: Generalization of Faustmanns formula for stochastic forest growth and prices with Markov decision process models. Forest Science, 47:466-474.

Burkhart, H. E., Tomé, M., 2012: Modeling Forest trees and planter stands. Springer, $457 \mathrm{p}$.

Campbell, G. S., 1986: Extinction coefficients for radiation in plant canopies calculated using an ellipsoidal inclination angle distribution. Agricultural and Forest Meteorology, 36:317-321.

Campbell, G. S., 1990: Derivation of an angle density function for canopies with ellipsoidal leaf angle distribution. Agricultural and Forest Meteorology, 49:173-176.

Černý, M., Bukša, I., 2005: Field-Map - Advanced measurement technology for forest management, nature conservation and landscaping. In: Conference proceedings, International anniversary scientific conference devoted to the 75 th anniversary of Ukrainian forestry research institute founding , 30 - 31 March 2005, Kharkov, Ukraine, p. 84-85.

Clark, M. L., Clark, D. B., Roberts, D. A., 2004: Smallfootprint lidar estimation of sub-canopy elevation and tree height in a tropical rain forest landscape. Remote Sensing of Environment, 91:68-89.

Clemence, B. S. E., 1997: A brief assessment of a weather data generator (CLIMGEN) at Southern African sites. Short Communication. Water SA, 23:271-274.

Clutter, J. L., 1963: Compatible growth and yield models for loblolly pine. Forest Science, 9:354-371.

Collalti, A., Perugini, L., Santini, M., Chiti, T., Nolè, A., Matteucci, G., Valentini, R., 2014. A process-based model to simulate growth in forests with complex structure: Evaluation and use of 3D-CMCC Forest Ecosystem Model in a deciduous forest in Central Italy. Ecological Modelling, 272:362-378.

Cornea, 2017: Webpage of CORNEA CAVE system at KAUST Visualization Core Lab (King Abdullah University of Science and Technology). Available at: http://kvl.kaust.edu.sa/Pages/cornea.aspx 2017, [accessed March 8, 2017].

Cruz-Neira, C., Sandin, D. J., DeFanti, T. A., 1993: Surround-screen projection-based virtual reality: the design and implementation of the CAVE. In: Proceedings of the 20th annual conference on Computer graphics and interactive techniques. ACM SIGGRAPH, p. 135-142.

Cruz-Neira, C., Sandin, D. J., DeFanti, T. A., Kenyon, R. V., Hart, J. C., 1992: The CAVE: audio visual experience automatic virtual environment. Communications of the ACM, 35:64-72.

Cyberith, 2017: CYBERITH GmbH webpage-Cyberith Virtualizer product description. Available at: http:// cyberith.com/2017, [accessed March 8, 2017].

de Willigen, P., 1991. Nitrogen turnover in the soil-crop system; comparison of fourteen simulation models. Fertilizer Research, 27:141-149.
Dealle, K., Rudemo, M., 1997: Automatic estimation of individual tree positions from aerial photos. Canadian Journal of Forest Research, 27:1728-1736.

Deckmyn, G., Verbeeck, H., Op de Beeck, M., Vansteenkiste, D., Steppe, K., Ceulemans, R., 2008.ANAFORE: A stand-scale process-based forest model that includes wood tissue development and labile carbon storage in trees. Ecological Modelling, 215:345-368.

DeFanti, T. A., Acevedo, D., Ainsworth, R. A., Brown, M. D., Cutchin, S., Dawe, G.et al., 2011: The future of the CAVE. Central European Journal of Engineering, 1:16-37.

DeFanti, T. A., Dawe, G., Sandin, D. J., Schulze, J. P., Otto, P., Girado, J. et al., 2009: The StarCAVE, a third-generation CAVE and virtual reality OptIPortal. Future Generation Computer Systems, 25:169-178.

Dieckmann, U., Law, R., Metz, J. A. J., 2000: The geometry of ecological interactions: Simplifying spatial complexity, Cambridge University Press, Cambridge, $564 \mathrm{p}$.

Donatelli, M., Bellocchi, G., Habyarimana, E., Bregaglio, S., Confalonieri, R., Baruth, B., 2009: CLIMA: a weathergenerator framework. In: 18th World IMACS / MODSIM Congress, Cairns, Australia, 13-17 July 2009, Avaiable at: http://mssanz.org.au/modsim09.

Dubrovský, M., 1997: Creating daily weather series with use of the weather generator. Environmetrics, 8:409-424.

Dufour-Kowalski S., Courbaud B., Dreyfus P., Meredieu C., de Coligny F., 2012. Capsis: an open software framework and community for forest growth modelling. Annals of Forest Science, 69:221-233.

Dufrêne, E., Davi, H., François, C., Maire, G. le, Dantec, V.L., Granier, A., 2005. Modelling carbon and water cycles in a beech forest. Ecological Modelling, 185:407-436.

Eckersten, H., Jansson, P.-E., 1991. Modelling water flow, nitrogen uptake and production for wheat. Fertilizer Research, 27:313-329.

Ek, A. R., Monserud, R. A., 1974: Trials with program FOREST: Growth and reproduction simulation for mixed species even- or uneven-aged forest stands. In: Fries, J. (Hrsg.): Growth models for tree and stand simulation. Royal College of Forestry, Stockholm, Sweden, Research Notes, 30:56-73.

Fabrika, M., 2005: Simulátor biodynamiky lesa SIBYLA. Koncepcia, konštrukcia a programové riešenie. Habilitačná práca, Technická univerzita vo Zvolene, 238 p.

Fabrika, M., Duurský, J., 2005: Algorithms and software solution of thinning models for SIBYLA growth simulator. Journal of Forest Science, 51:431-445.

Fabrika, M., Ďurský, J., 2006: Implementing Tree Growth Models in Slovakia. In: Hasenauer, H. (Ed.), Sustainable Forest Management: Growth Models for Europe. Springer Berlin Heidelberg, Berlin, Heidelberg, p. 315-341. 
Fabrika, M., Pretzsch, H., 2013: Forest Ecosystem Analysis and Modelling. Technical University in Zvolen, $619 \mathrm{p}$.

Fan, Y., Roupsard, O., Bernoux, M., Le Maire, G., Panferov, O., Kotowska, M.M., Knohl, A., 2015. A sub-canopy structure for simulating oil palm in the Community Land Model (CLM-Palm): phenology, allocation and yield. Geoscientific Model Development, 8:3785-3800.

Febretti, A., Nishimoto, A., Thigpen, T., Talandis, J., Long, L., Pirtle, J. D. et al., 2013: CAVE2: A Hybrid Reality Environment for Immersive Simulation and Information Analysis. In: IS\&T/SPIE Electronic Imaging. International Society for Optics and Photonics, p. 864903-864903-12.

Fernandes, K. J., Raja, V., Eyre, J., 2003: Immersive learning system for manufacturing industries. Computers in Industry, 51:31-40.

Fox, T. R., Allen, L., Wynne, R. H., Blinn, Ch. E., 2008: Precision Silviculture in the 21st Century: Linking GIS and Remote Sensing to Develop Site Specific Silvicultural Regimes in Southern Pine Plantations, In: Bettinger, P., Merry, K., Frei, S., Drake, J., Nibbelink, Heinstall, (eds.): Proceedings of the 6th Southern Forestry and Natural Resources GIS Conference. Warner School of Forestry and Natural Resources, University of Georgia, Athens.

Franc, A., Gourlet-Fleury, S., Picard, N., 2000: Une Introduction á la Modélisation des Forêts Hétérogènes. ENGREF, Nancy, France.

Franz, F., 1968: das EDV-Programm STAOET - zur Herleitung mehrgliedriger Standort-Leistungstafeln. Manuskriptdruck, München unveröff.

Gadow, von K., 1987: Untersuchungen zur Konstruktion von Wuchsmodellen für schnellwüchsige Plantagenbaumarten. Forstliche Forschungsber. München, No. 77, 147 p.

Geng S., Auburn, J., Brandstetter, E., Li, B., 1988: A Program to Simulate Meteorological Variables. Documentation for SIMMETEO. (Agronomy Report No. 204). University of California, Davis Crop Extension, Davis, California.

Geng, S., Penning De Vries, F. W. T., Supit, I., 1986: A simple method for generating daily rainfall data. Agricultural and Forest Meteorology, 36:363-376.

Gitelson, A. A., Kaufman, Y. J., Stark, R., Rundquist, D., 2002: Novel algorithm for remote estimation of vegetation fraction. Remote Sensing of Environment, 80: 76-87.

Gougeon, F. A., 1995: A crown following approach to the automatic delineation of individual tree crowns in high spatial resolution aerial images. Canadian Journal of Remote Sensing, 21:274-284.

Grote, R., 1998. Integrating dynamic morphological properties into forest growth modelling. Forest Ecology and Management, 111:193-210.
Grote, R., Kiese, R., Grünwald, T., Ourcival, J.-M., Granier, A., 2011. Modelling forest carbon balances considering tree mortality and removal. Agricultural and Forest Meteorology, 151:179-190.

Grote, R., Pretzsch, H., 2002. A Model for Individual Tree Development Based on Physiological Processes. Plant Biology, 4:167-180.

Grote, R., Pretzsch, H., 2002: A model for individual tree development based on physiological processes. Plant Biology, 4:167-180.

Grote, R., Reiter, I.M., 2004. Competition-dependent modelling of foliage biomass in forest stands. Trees, 18.

Guillemot, J., Francois, C., Hmimina, G., Dufrêne, E., Martin-StPaul, N. K. et al., 2016: Environmental control of carbon allocation matters for modelling forest growth. New Phytologist, 214:180-193.

Halaj, et al., 1987: Rastové tabulky hlavných drevín ČSSR. Bratislava, Príroda, 361 p.

Hamilton, G., Christie, J. M., 1973: Construction and application of stand yield tables. British For. Com. Res. and Developm. Paper, London, No. 96, 14 p.

Hansen, J. W., Mavromatis, T., 2001: Correcting lowfrequency variability bias in stochastic weather generators. Agricultural and Forest Meteorology, 109:297-310.

Harding, D. J., Lefsky, M. A., Parker, G. G., Blair, J. B., 2001: Laser altimetry canopy height profiles methods and validation for closed-canopy, broadleaf forests. Remote Sensing of Environment, 76:283-297.

Hauhs, M., Kastner-Maersch, A., Rost-Siebert, K., 1995: A model relating forest growth to ecosystem-scale budgets of energy and nutrients. Ecological Modelling, 83:229-243.

Hayhoe, H. N., 2000: Improvements of stochastic weather data generators for diverse climates. Climate Research, 14:75-87.

Heurich, M., Schneider, T., Kennel, E., 2003: Laser Scanning for Identification of Forest Structures in the Bavarian Forest National Park. In: Hyyppä, Naesset, Olsson, Pahlen, Reese (eds.): Proceedings of the Scandlaser Scientific Workshop on Airborne Laser Scanning of Forests., p. 97-106.

Heurich, M., Perssson, A., Holmgren, J., Kennel, E., 2004: Detecting and measuring individual trees with laser scanning in mixed mountain forest of Central Europe using an algorithm developed for Swedish boreal forest conditions. International Archives Photogrammetry, Remote Sensing and Spatial Information Sciences, XXXVI:307-312.

Hidy, D., Barcza, Z., Marjanović, H., Ostrogović Sever, M.Z., Dobor, L., Gelybó, G. et al., 2016. Terrestrial Ecosystem Process Model Biome-BGCMuSo: Summary of improvements and new modeling possibilities. Geoscientific Model Development Discussions, p. $1-60$. 
Holdridge, L. R., 1947: Determination of World Plant Formations from Simple Climatic Data. Science, 105: 367-369.

Holmgren, J., Persson, Å., 2004: Identifying species of individual trees using airborne laser scanner. Remote Sensing of Environment, 90:415-423.

Hopkinson, C., Chasmer, L., Young-Pow, C., Treitz, P., 2004: Assesing forest metrics with a ground-based scanning lidar. Canadian Journal of Forest Research, 34:573-583.

Houllier, F., 1995: A propos des modèles de la dynamique des peuplements hétérogènes structures, processus démographiques et mécanismes de regulation. Revue d'Écologie, 50: 273-282.

Hurtt, G. C., Moorcroft, P. R., Pacala, S. W., 2013: Ecosystem Demography Model: Scaling Vegetation Dynamics Across South America.

Huth, R, Mládek, R., Metelka, L., Sedlák, P., Huthová, Z., Kliegerová, S. et al., 2003: On the integrability of limited-area numerical weather prediction model ALADIN over extended time periods. Studia Geophysica et Geodaetica, 47:863-873.

Jansson, P.-E., Karlberg, L., 2004: Coupled heat and mass transfer model for soil-plant-atmosphere systems. Royal Institute of Technology, Department of Civil and Environmental Engineering.

Jonard, M., André, F., 2018: Heterofor [Capsis] [WWW Document].URL http://capsis.cirad.fr/capsis/help_ en/heterofor (accessed 12.8.18).

Jones, P. G., Thornton, P. K., 2000: MarkSim: software to generate daily weather data for Latin America and Africa. Agronomy Journal, 92:445-453.

Kahn, M., 1994: Modellierung der Höhenentwicklung ausgewählter Baumarten in Abhängigkeit vom Standort. Forstliche Forschungsber. München, Vol. 141, 221 p.

Karjalainen, E., Tyrväinen, L., 2002: Visualization in forst lanscape preference reaearch: a Finnish perspective. Lanscape and Urban Planning, 59:13-28.

Keenan, T., Niinemets, Ü., Sabate, S., Gracia, C., Peñuelas, J., 2009. Process based inventory of isoprenoid emissions from European forests: model comparisons, current knowledge and uncertainties. Atmospheric Chemistry and Physics, 9: 4053-4076.

Kimmins, H., Blanco, J. A., Seely, B., Welham, C., Scoullar, K., 2010: Forecasting Forest Futures - A Hybrid Modelling Approach to the Assessment of Sustainability of Forest Ecosystems and Their Values. New York, Earthscan, 304 p.

King, A. W., 1991: Translating models across scales in the landscape. In: Turner, M. G., Gardner, R. H. (eds.). Quantitative methods in landscape ecology: the analysis and interpretation of landscape heterogeneity, New York, Springer, Vol. 82, p. 470-517.
Klemmt, H. J., Tauber, R., 2008: Automatisierte Ermittlung forstinventurrelevanter Parameter aus 3D-Laserscanning-Daten sowie aus 2D-DendroScandaten - Eine vergleichende Feldstudie. In: DVFFA - Sektion Ertragskunde, Jahrestagung 2008, Trippstadt, 5.-8. Mai 2008, p. 169-179.

Kniemeyer, O., 2008: Design and Implementation of a Graph Grammar Based Language for Functional-Structural Plant Modelling. Dissertation. Fakultät für Mathematik, Naturwissenschaften und Informatik der Brandenburgischen Technischen Universität Cottbus, $432 \mathrm{p}$.

Koreň, M., Mokroš, M., Bucha, T., 2017: Accuracy of tree diameter estimation from terrestrial laser scanning by circle-fitting methods. International Journal of Applied Earth Observation and Geoinformation, 63:122-128.

Kramer, K., Buiteveld, J., Forstreuter, M., Geburek, T., Leonardi, S., Menozzi, P. et al., 2008: Bridging the gap between ecophysiological and genetic knowledge to assess the adaptive potential of European beech. Ecological Modelling, 216:333-353.

Kramer, K., van der Werf, B., Schelhaas, M. J., 2015: Bring in the genes: genetic-ecophysiological modeling of the adaptive response of trees to environmental change. With application to the annual cycle. Frontiers in Plant Science, 5:742.

Kramer, K., van der Werf, D. C., 2010: Equilibrium and non-equilibrium concepts in forest genetic modelling: population- and individually-based approaches. Forest Systems, 19:100-112.

Kurth, W., 1994: Growth Grammar Interpreter GROGRA 2.4: A software tool for 3-dimensional interpretation of stochastic, sensitive growth grammars in the context of plant modelling. Intoduction and Reference Manual. Berichte des Forsungszentrums Waldökosysteme der Universität Göttingen, Ser. B, Vol. 38, 192 p.

Kurth, W., 1999: Die Simulation der Baumarchitektur mit Wachstumsgrammatiken. Wissenschaftlicher Verlag Berlin, 327 p.

Landsberg, J., Sands, P., 2011: Physiological Ecology of Forest Production, Principles, Processes and Models, Volume 4 in the Terrestrial Ecology Series. Elsevier Inc., $331 \mathrm{p}$.

Landsberg, J. J., Waring, R. H., 1997: A generalised model of forest productivity using simplified concepts of radiation-use efficiency, carbon balance and partitioning. Forest Ecology and Management, 95:209-228.

Lembcke, G., Knapp, E., Dittmar, O., 1975: Die neue DDR-Kiefernertragstafel 1975. Beiträge für die Forstwirtschaft, 15:55-64.

Lexer, M. J., Hönninger, K., 2001: A modified 3D-patch model for spatially explicit simulation of vegetation composition in heterogeneous landscapes. Forest Ecology and Management, 144:43-65. 
Liang, X., Kankare, V., Hyyppä, J., Wang, Y., Kukko, A., Haggrén, H. et al., 2016. Terrestrial laser scanning in forest inventories. ISPRS Journal of Photogrammetry and Remote Sensing, 115:63-77.

Lim, K., Treitz, P., Wulder, M., St-Onge, B., Flood, M., 2003: LIDAR remote sensing of forest structure. Progress in Physical Geography, 27:88-106.

Lischke, H., 2001: New developments in forest modeling: convergence between applied and theoretical approaches. Natural Ressource Modeling, 14:71-102.

Lischke, H., Löffler, Th. J., Thornton, P. E., Zimmermann, N. E., 2006: Model up-scaling in landscape research. In: Kienast et al. (eds): A Changing World. Challenges for Landscape Research, p. 259-282.

Lischke, H., Zimmermann, N. E., Bolliger, J., Rickebusch, S., Löffler, T. J., 2006: TreeMig: A forest-landscape model for simulating spatio-temporal patterns from stand to landscape scale. Ecological Modelling, 199:409-420.

Liu, J. G., Ashton, P.S., 1998: FORMOSAIC: An Individual Based, Spatially Explicit Model for Simulating Forest. In: Dynamics in Landscape Mosaics, Ecological Modelling, p. 106-177.

Loustau, D., 2010. Forests, Carbon Cycle and Climate Change. Editions Quae.

Loustau, D., Bosc, A., Colin, A., Ogee, J., Davi, H., Francois, C. et al., 2005: Modeling climate change effects on the potential production of French plains forests at the sub-regional level. Tree Physiology, 25:813-823.

Magnussen, S., Boudewyn, P., 1998: Derivations of stand heights from airborne laser scanner data with canopy-based quantile estimators. Canadian Journal of Forest Research, 28:1016-1031.

McCaskill, M. R., 1990: TAMSIM-a program for preparing meteorological records for weather driven models. Tropical Agronomy Technical Memorandum, No. 65.

McGaughey, R. J., 1997: Visualizing forest stand dynamics using the stand visualization system. In: Seattle, W.A., Bethesda, D: Proceedings of the 1997, ACSM/ ASPRS Annual Convention and Exposition; April 7-10, 1997. American Society for Photogrammetry and Remote Sensing, 4:248-257.

Medvigy, D., Wofsy, S. C., Munger, J. W., Hollinger, D. Y., Moorcroft, P. R., 2009: Mechanistic scaling of ecosystem function and dynamics in space and time: Ecosystem Demography model version 2. Journal of Geophysical Research-Biogeosciences, 114 p.

Merganič, J., Sterba, H., 2006: Characterisation of diameter distribution using the Weibull function: method of moments. European Journal of Forest Research, 125:427-439.

Merrill,S., 2009:KAUST:Visualizationbeyond theCAVE. Available at: http://techcrunch.com/2009/09/22/ kaust-visualization-beyond-the-cave/ September 22, 2009, [accessed March 8, 2017].
Mikita, T., Janata, P., Surový, P., 2016. Forest stand inventory based on combined aerial and terrestrial close-range photogrammetry. Forests, 7: 1-14.

Mohan, M., Silva, A. C., Klauberg, C., Jat, P., Catts, G., Cardil, A. et al., 2017: Individual Tree Detection from Unmanned Aerial Vehicle (UAV) Derived Canopy Height Model in an Open Canopy Mixed Conifer Forest. For.

Mokroš, M., Liang, X., Surový, P., Valent, P., Černňava, J., Chudý, F. et al., 2018a: Evaluation of Close-Range Photogrammetry Image Collection Methods for Estimating Tree Diameters. ISPRS International Journal of Geo-Information, 7:1-13.

Mokroš, M., Výboštok, J., Tomaštík, J., Grznárová, A., Valent, P., Slávik, M., Merganič J., 2018b: High Precision Individual Tree Diameter and Perimeter Estimation from Close-Range Photogrammetry. Forests, 9:1-12.

Moser, J. W., 1974: A system of equations for the components of forest growth. In: Fries, J. (Hrsg.): Growth models for tree and stand simulation. Royal College of Forestry, Stockholm, Sweden, Research Notes, No. 30, 397 p.

Munro, D. D., 1974: Forest growth-models: A prognosis. In: Fries, J. (ed.): Growth models for tree and stand simulation. Royal College of orestry Res Notes, 30, Stockholm, p. 7-21.

Nagel, J., 1996: Anwendungsprogramm zur Bestandesbewertung und zur Prognose der Bestandesentwicklung. Forst und Holz, 3:76-78.

Nagel, J., Biging, G. S., 1995: Schätzung der Parameter derWeibullfunktion zur Generierung von Durchmesserverteilungen. Allgemeine Forst- und Jagdzeitung, 166:185-189.

Naudts, K., Ryder, J., McGrath, M. J., Otto, J., Chen, Y., Valade, A. et al., 2015: Avertically discretised canopy description for ORCHIDEE (SVN r2290) and the modifications to the energy, water and carbon fluxes. Geoscientific Model Development, 8:2035-2065.

Oculus, 2017: Oculus Rift - Virtual Reality Headset for 3D Gaming | Oculus VR ${ }^{\circledR}$ webpage-product description. Available at: http://oculus.com/ 2017, [accessed March 8, 2017].

Oleson, K. W., Lawrence, D. M., Bonan, G. B., Drewniak, B., Huang, M., Levis, S. et al., 2013: Technical Description of version 4.5 of the Community Land Model (CLM), 434 p.

Orland, B., (ed.), 1992: Data Visualization Techniques in Environmental Managament. Special Issue, Landscape Urban Planning, 21:237-319.

Orland, B., 1997: Final Report: SmartForest. Part II. Forest visual modeling for forest pest management and planning. USDA Forest Service, FPM-FHTET, State and Private Forestry, Washington, DC. 
Parton, W. J., Schimel, D. S., Cole, C. V., Ojima, D. S., 1987: Analysis of Factors Controlling Soil Organic Matter Levels in Great Plains Grasslands 1. Soil Science Society of America Journal, 51:1173-1179.

Persson, Å., Holmgren, J., Söderman, U., 2002: Detecting and measuring individual trees using an airborne laser scanner. Photogrammetric Engineering \& Remote Sensing, 68:925-932.

Perttunen, J., Sievänen, R., Nikinmaa, E., 1998: LIGNUM: a model combining the structure and the functioning of trees. Ecological Modelling, 108:189-198.

Pfeifer, N., Gorte, B., Winterhalder, D., 2004: Automatic reconstruction of single trees from terrestrial laser scanner data, ISPRS - International Archieves of Photogrammetry, Remote Sensing and Spatial informatik Sciebce. Vol. XXXV, Part B: 114-119.

Pfreundt, J., 1988: Modellierung der räumlichen Verteilung von Strahlung, Photosynthesekapazität und Produktion in einem Fichtebestand und ihre Beziehung zur Bestandesstruktur. Dissertation, Universität Göttingen, 163 p.

Polhemus, 2017: POLHEMUS innovation to motionTM webpage-Electromagnetic motion tracking systems. Available at: http://polhemus.com/2017, [accessed March 8, 2017].

Pommerening, A., 1999: Methoden zur Reproduktion und Forstschreibung einzelner konzentrischer Proberkreise von Betriebs- und Landeswaldinventuren. In DVFF - Sektion Ertragskunde, Volpriehausen.

Pommerening, A., Biber, P., Stoyan, D., Pretzsch, H., 2000: Neue Methoden zur Analyse und Charakterisierung von Bestandesstrukturen. Photogrammetric Engineering \& Remote Sensing, 119 p.

Popescu, S.,Wynne, R. H., Nelson, R. F., 2002: Estimating plot-level tree heights with lidar: local filtering with a canopy-height based variable window size. Computers and Electronics in Agriculture, 37:71-95.

Porte, A., Bartelink, H. H., 2002: Modelling mixed forest growth a review of models for forest management. Ecological Modelling, 150:141-188.

Prentice, I. C., Cramer, W., Harrison, S. P., Leemans, R., Monserud, R. A., Solomon, A. M., 1992: A global biome model based on plant physiology and dominance, soil properties and climate. Journal of Biogeography, 19:117-143.

Pretzsch, H., 1997: Analysis and modeling of spatial stand structures. Methodological considerations based on mixed beech-larch stands in Lower Saxony, Forest Ecology Management, 97:237-253.

Pretzsch, H., 2001: Modellierung des Waldwachstums. Parey Buchverlag Berlin, $341 \mathrm{p}$.

Pretzsch, H., 2009: Forest Dynamics, Growth and Yield. From Measurement to Model. Springer, 664 p.

Pretzsch, H., Biber, P., Durský, J., 2002: The single treebased stand simulator SILVA: construction, application and evaluation, Forest Ecology and Management, 162:3-21.
Pretzsch, H., Grote, R., Reineking, B., Rötzer, T. H., Seifert, S. T., 2007: Models for forest ecosystem management: a European perspective. Annals of Botany, 101:1065-1087.

Prusinkiewicz, P., Lindenmayer, A., 1990: The Algorithmic Beauty of Platns. Springer-Verlag, New York, $228 \mathrm{p}$.

Puliti, S., Gobakken, T., Ørka, H.O., Næsset, E., 2017. Assessing 3D point clouds from aerial photographs for species-specific forest inventories. Scandinavian Journal of Educational Research, 32:68-79.

Rastetter, E. B., King, A. W., Cosby, B. J., Hornberger, G. M., Oneill, R. V., Hobbie, J. E., 1992: Aggregating Fine-Scale Ecological Knowledge to Model Coarser-Scale Attributes of Ecosystems. Ecological Applications, 2:55-70.

Richardson, C.W., Wright, D.A., 1984:WGEN: a model for generating daily weather variables. U.S. Department of Agriculture, Agricultural Research Service, ARS-8, Washington, D.C, USA.

Rötzer, T., Leuchner, M., Nunn, A. J., 2010: Simulating stand climate, phenology, and photosynthesis of a forest stand with a process-based growth model. International Journal of Biometeorology, 54:449464.

Rötzer, T., Seifert, T., Gayler, S., Priesack, E., Pretzsch, H., 2012. Effects of Stress and Defence Allocation on TreeGrowth: Simulation Results at the Individual and Stand Level. In: Matyssek, R., Schnyder, H., Oßwald, W., Ernst, D., Munch, J. C., Pretzsch, Hans (eds.), Growth and Defence in Plants: ResourceAllocation at Multiple Scales, Ecological Studies. Springer Berlin Heidelberg, Berlin, Heidelberg, p. 401-432.

Rötzer, T., Seifert, T., Pretzsch, H., 2009: Modelling above and below ground carbon dynamics in a mixed beech and spruce stand influenced by climate. European Journal of Forest Ressearch, 128:171-182.

Running, S., Hunt, E., 1993. Generalization of a Forest Ecosystem Process Model for Other Biomes, BIOMEBCG, and an Application for Global-Scale Models. Scaling Physiological Processes: Leaf to Globe: A volume in Physiological Ecology, p. 141-158.

Scheller, R., Hua, D., Bolstad, P., A. Birdsey, R., Mladenoff, D., 2011: The effects of forest harvest intensity in combination with wind disturbance on carbon dynamics in Lake States Mesic Forests, 222:144-153.

Schmidt, A., 1971: Wachstum und Ertrag der Kiefer auf wirtshaftlich wichtigen Standorteinheiten der Oberpfalz. Forstliche Forschungsber. München, Bd. 1, 178 p.

Seidl, R., Baier, P., Rammer, W., Schopf, A., Lexer, M. J., 2007: Modelling tree mortality by bark beetle infestation in Norway spruce forests. Ecological Modelling, 206:383-399. 
Seidl, R., Lexer, M. J., Jäger, D., Hönninger, K., 2005: Evaluating the accuracy and generality of a hybrid patch model. Tree Physiology, 25:939-951.

Seidl, R., Rammer, W., Bellos, P., Hochbichler, E., Lexer, M. J., 2009: Testing generalized allometries in allocation modeling within an individual-based simulation framework. Trees, 24:139-150.

Seidl, R., Rammer, W., Scheller, R. M., Spies, T. A., 2012: An individual-based process model to simulate landscape-scale forest ecosystem dynamics. Ecological Modelling, 231:87-100.

Seidl, R., Thom, D., Kautz, M., Martin-Benito, D., Peltoniemi, M., Vacchiano, G. et al., 2017: Forest disturbances under climate change. Nature Climate Change, 7:395.

Semenov, M. A., Brooks, R. J., Barrow, E. M., Richardson, C. W., 1998: Comparison of WGEN and LARS-WG stochastic weather generators for diverse climates. Climate Resourses, 10:95-107.

Shinozaki, K., Yoda, K., Hozumi, K., Kira, T., 1964: A Quantitative analysis of plant form-the pipe model theory: i. Basic analyses. Japanese Journal of Ecology, 14:97-105.

Shugart, H. H., 1984: A Theory of Forest Dynamics. The Ecological Implications of Forest Succesion Models. Springer-Verlag New York, Berlin, Heidelberg, Tokio, $278 \mathrm{p}$.

Shugart, H. H., West, D. C., 1977: Development of an Appalachian deciduous forest succesion model and its application to assessment of the impact of the chestnut blight. Journal of Environmental Management, 5:161-179.

Sievänen, R., Perttunen, J., Nikinmaa, E., Kaitaniemi, P., 2008: Toward extension of a single tree functionalstructural model of Scots pine to stand level: effect of the canopy of randomly distributed, identical trees on development of tree structure. Functional Plant Biology, 35:964-975.

Simonse, M., Aachhoff, T., Spiecker, H., Thies, M., 2003: Automatic Determinantion of Forest inventory parameters using terrestrial laser scanning, Institute for Growth, Freiburg, ScandLaser scientific Workshop on Airborne Laser Scanning, p. 1-7.

Sitch, S., Smith, B., Prentice, I. C., Arneth, A., Bondeau, A., Cramer, W. et al., 2003. Evaluation of ecosystem dynamics, plant geography and terrestrial carbon cycling in the LPJ dynamic global vegetation model. Global Change Biology, 9:161-185.

Sloboda, B., 1976: Mathematische und stochastische Modelle zur Beschreibung der Statik und Dynamik von Bäumen und Beständen - insbesondere das bestandesspezifische Wachstum als stochasticher Prozeß. Habil.-Schrift, Univ. Freiburg, 310 p.
Smith, B., Prentice, I. C., Sykes, M. T., 2001: Representation of vegetation dynamics in the modelling of terrestrial ecosystems: comparing two contrasting approaches within European climate space. Global Ecology and Biogeography, 10:621-637.

Smith, B., Wårlind, D., Arneth, A., Hickler, T., Leadley, P., Siltberg, J., Zaehle, S., 2014: Implications of incorporating $\mathrm{N}$ cycling and $\mathrm{N}$ limitations on primary production in an individual-based dynamic vegetation model. Biogeosciences, 11:2027-2054.

Sodtke, R., Schmidt, M., Fabrika, M., Nagel, J., Ďurský, J., Pretzsch, H., 2004: Anwendung und Einsatz von Einzelbaummodellen als Komponenten von entscheidungsunterstützenden Systemen für die strategische Forstbetriebsplannung. Forstarchiv, 75:51-64.

Sterba, H., 1995: PROGNAUS - ein absandsunabhängiger Wachstumssimulator für ungleichaltrige Mischbestände. DVFF - Sektion Ertragskunde, Joachimstahl, p. 173-183.

Surový, P., Ribeiro, N., Oliveira, A. C., Scheer, L', 2004: Discrimination of vegetation from the background in high resolution colour remote sensed imagery. Journal of Forest Science, 50:161-170.

Suzuki, T., 1971: Forest transition as a stochastic process. Mitt. der Forstlichen Bundesversuchsanstalt Wien, 91:137-150.

Svensson, M., Jansson, P.-E., Kleja, D. B., 2008. Modelling Soil C Sequestration in Spruce Forest Ecosystems along a Swedish Transect Based on Current Conditions. Biogeochemistry, 89:95-119.

Thornton, P., Running, S. W., Hunt, E. R., 2005: BiomeBGC: Terrestrial Ecosystem Process Model, Version 4.1.1.

Urban, D. L., 2005: Modeling ecological processes across scales. Ecology, 86:1996-2006.

Van Oijen, M., Rougier, J., Smith, R., 2005: Bayesian calibration of process-based forest models: bridging the gap between models and data. Tree Physiology, 25:915-927.

Vanclay, J. K., 1994: Modelling forest growth and yield (Application to mixed tropical forests). CAB International, Wallingford, UK, $312 \mathrm{p}$.

Vicon Bonita, 2014: Vicon Motion Systems Ltd - Optical motion capture systems - webpage. Avaiable at: http://www.vicon.com/system/bonita 2014, [accessed November 9, 2014].

Virtuix, 2017: Virtuix OmniTM webpage-product description. Available at: http://virtuix.com/ 2017, [accessed March 8, 2017].

Virtusphere, 2017: CVirtusphere, Inc. webpage. Virtusphere product description. Available at: http:// www.virtusphere.com/index.html 2017, [accessed March 8, 2017].

VRAC, 2008: Webpage of C-6 CAVE system at Virtual Reality Application Center (Iowa State University). Available at: http://www.vrac.iastate.edu/c6.php 2008, [accessed March 8, 2017]. 
Vuokila, Y., 1966: Functions for variable density yield tables of pine based on temporary sample plots. Communicationes Instituti Forestalis Fenniae, 60: 86.

Warnant, P., FrançOis, L., Strivay, D., GéRard, J.-C., 1994. CARAIB: A global model of terrestrial biological productivity. Global Biogeochemical Cycles 8: 255-270.

Weiskittel, A. R., Hann, D. W., Kershaw, Jr., J. A., Vanclay, J. K., 2011: Forest Growth and Yield Modeling. Wiley-Blackwell, 415 p.
Woodward, F. I., Smith, T. M., 1994: Predictions and Measurements of the Maximum Photosynthetic Rate at the Global Scale, In: Schulze, E. D., Caldwell, M. M. (eds.): Ecological Studies 100, Springer-Verlag, New York, p. 491-509.

Wykoff, W. R., Crookston, N. L., Stage, A. R., 1982: User's Guide to the stand prognosis model. U. S. For. Serv., Gen. Techn. Rep. INT-133, Ogden, Utah, $112 \mathrm{p}$. 